\title{
Workload Analysis on Local Bureaucracies
}

\author{
Fernandes Simangunsong \\ Institut Pemerintahan Dalam Negeri \\ Jatinangor West Java, Indonesia \\ kisankiel@yahoo.co.id
}

\begin{abstract}
The purpose of this study was to analyze workload of organisasi perangkat daerah (OPD) (local bureaucracies) in Bekasi regency. In this study, the workload of all units of local bureaucracies was measured by calculating the efficiency and effectiveness of each positions in local bureaucracies and required number of personnel in every local bureaucracies. This study used concept of personnel administration and specific concept on workload analysis in which this study developed a pattern to evaluate the work implementation, work process and work result. Later, by this analysis, it is probable to determine required number of personnel of all local bureaucracies in Bekasi regency was. This study is included as applied research and also observational research in which it collects data from phenomena to interpret primary data obtained by interview, observation, and focus group discussion (FGD) to all leaders of local bureaucracies and their personnel at the level of regional secretariat, council secretariat, inspectorate, office, agency, district and subdistrict in total of 59 agencies.
\end{abstract}

Keyword: workload analysis, personnel local bureaucracies

\section{INTRODUCTION}

Human resources are vital and determinant in the process of national development. Human resources are one of main instrument in the seeking for improvement of technological advancement in this globalization era. Generally Indonesia, there are limited number of quality human resources. This disadvantage also happens in government sector. Lack of human resources in this sector requires government to improve the empowerment of administrative apparatus. One way to establish policy of apparatus empowerment is by calculating workload. Workload is one of main indicators in the structuring of employees and empowerment of administrative apparatus.

Organizational structure plays a role in determining the allocation of resources in some organizational units to achieve future purposes. The resources allocated include human resources. Allocation of human resources appropriately to each units will ensure the effectiveness and efficiency so that optimum performance of the units can be achieved. Here, effectiveness can be defined as number of personnel to be allocated in order to achive goals and objectives of the unit, while efficiency is allocation of appropriate number of personnel that would affect the efficiency in financing the organizational units.

Workload analysis is study on amount of work volume assigned to a unit of organization in order to interpret strategic policies in the future. Workload is amount of output to be produced within certain period, which is generally measured in quantitative numbers. Workload for administrative tasks seems qualitative, therefore it is necessary to have a standard on measurement of workload for administrative tasks according to effective and efficient principles of organization.

Workload of governmental agencies, in general, is still given less attention, and thus their performance can not be reviewed in terms of workload. Ability, motivation of human resources, and capability of the agencies are frequently considered as main cause of problems in the work process within governmental agencies. Till today, workload of an agencyis still not used as an indicator in the study to examine the decreasing performance of the agency.

For effectiveness and efficiency of organization in all fields and subfields, it is necessary to have appropriate quantity and quality of personnel as required. Therefore, workload analysis in each units of organization is required to define the quantity of personnel. However, until now, the measurement of workload is still not taking into account the available resources or inputs and relating them to the operationalization of vision and missions of central, provincial, and regency governments and agencies. This frequently results in the instability of work volume ofwhich there is a growing pile of work in certain period and none in other period. This measurement of workload is intended to provide recommendations for appropriate structure of organization according to workload assigned by the organization. This workload analysis is part of management system to calculate amount of tasks that should be accomplished by a unit of organization in continual basis.

Based on background above, then it is necessary to examine the workload of each position and the lowest work unit by workload analysis. Workload analysis is aimed to improve the optimization of performance in government agencies. Result of the analysis can be considered as benchmark for organizational structuring according to requirement for accomplishment of assigned tasks. The measurement of this workload is a study to get an overview onthe implementation or amount of job descriptions assigned by an organization. Workload analysis on all Satuan Kerja Perangkat Daerah (SKPD) (Local Government Agencies) in Bekasi Regency Government was intended to measure the workload of each units in every Local Government Agencies, to measure the effectiveness and efficiency of each positions and units in every Local Government Agencies, and to calculate the required number of personnel for each positions and units in every Local Government Agencies.

Workload analysis can provide standard on measurement of personnel workload in an agency, as reference for required number of personnel in each lowest unitsand as performance 
assessment of positions and units, in order to improve the work system and procedure, to increase institutional performance, to set standard on workload of positions/agencies, to prepare personnel list or standard on structural position of echelon, to decide the required number of personnel according to workload of organization, to plan personnel transfer program from unit with exceeded number of personnel to other unit with deficient number of personnel, to plan personnel promotion program and reward and punishment, to improve training programs and to facilitate leader in policymaking for better empowerment of human resources.

Result of this study will provide recommendations on job description for positions in each lowest units, effectiveness and efficiency of positions and units, performance of positions and units, required number of personnel, amount of workload for positions and units, and standard on working time. As reference in this study, these are several legal regulations that specifically regulate on job analysis and workload analysis:

1. Law of the Republic of Indonesia No. 32 of 2004 on Local Government.

2. Law of the Republic of Indonesia No. 8 of 1974 on Personnel Principlesin junction withLaw No. 43 of 1999 on Amendment of Law No. 8 of 1974.

3. Decree of Minister of Home Affairs of the Republic of Indonesia No. 12 of 2008 on Guidelines for Workload Analysis in Department of Home Affairs and Local Government.

4. Decree of Head of State Civil Service Agency No. 19 of 2011 on Guidelines for Calculation of Required Civil Servant.

The implementation of Law No. 32 of 2004 on Local Government has changed the authority of Central and Local Government, which eventually bring implication on the change of organizational workload and structure. Local Government of province, regency, and city, through institutions (agency, body, and office), has many functions and roles in public services. For this activity, structure of several functions and tasks included as workload need to be implemented.

Workload analysis is basically expected to satisfy the demand of enabling effectiveness and efficiency and professionalism of the personnel/human resources in each agencies to be able to properly implement general development and administrative tasksaccording to Law No. 43 of 1999 on Personnel Principles stating that as the element of state aparatus Civil Servant should provide public services professionally.

Result of workload analysis can be used as benchmark for increasing work productiveness and other actions in order to advance the development, improvement and empowerment of state aparatus in terms of organizational, management, and personnel.

\section{RESULTS AND DISCUSSION}

Workload, in general, is amount of work that need to be accomplished within period of one year by a unit of organization. Measurement of workload is meant to produce recommendation on policy of organizational structuring to optimize its performance. Measurement result can be used to assess the work effectiveness, efficiency, and performance, to calculate number of required personnel per position and also to evaluate the structure of organization.

Workload analysis is important to be used as reference for decisionmaking at management level along with its various development, both in terms of organization, management, and personnel/human resources. Considering its significance in the development of organization, management, and human resources, it is therefore necessary to perform workload analysis within Bekasi regency government. Result of workload analysis is expected to be taken into consideration by Local Civil Servant Administrator of Bekasi regency in organizational structuring, personnel transfer and promotion, evaluation of task accomplishment, assessment of work performance, and control.

Workload analysis on each work units is meant to identify whether every holders of position have work product. With information on job description, it is possible to measure the workload, namely by defining unit indicator of result, time of completion, time norm (standard working time), work volume, and required personnel.

Object of analysis to calculate organizational workload of local government agency in Bekasi regency is all units of organization in Bekasi regency government according to Regional Regulation No. 7 of 2009 on Local Bureaucracies of Bekasi Regency as amended by Regional Regulation No. 6 of 2011 on Amendment of Regional Regulation No. 7 of 2009 on Local Bureaucracies of Bekasi Regency, excluding Local Hospital, Puskesmas(Community Health Center), UPTD (Regional Technical Implementation Unit) of Local Health Lab, UPTD of Occupational Health, UPTD of Personnel Health Care Polyclinic, and also all Elementary Schools, Junior and Senior and Vocational High Schools.

This exclusion is based on consideration that the result of this workload analysis is not only meant to identify the effectiveness and efficiency of work unit and position, but also to calculate number of personnel according to organizational workload. According to Decree of Head of State Civil Service Agency No. 19 of 2011 on Guidelines for Calculation of Required Civil Servant, functional position of teacher and specific functional positions and general functional position, specifically for Health Workers, are calculated separately according to guidelines specified by the parental institutions, i.e. Ministry of Education and Ministry of Health.

In addition to Local Bureaucracies as stated in Regional Regulation No. 7 of 2009 on Local Bureaucracies of Bekasi Regency in junction with Regional Regulation No. 6 of 2011 on Amendment of Regional Regulation No. 7 of 2009 on Local Bureaucracies of Bekasi Regency, there is also Local Bureaucracy that undergo transition into vertical institution, i.e. Secretariat of General Election Commission. In line with Law No. 15 of 2011 on Implementation of Gneral Election,KPUD (Komisi Pemilihan Umum Daerah) (Regional General Election Commission)is a hierarchical unit of General 
Election Commission and Provincial General Election Commission under same personnel management (Article 56). Therefore, in spite of personnel of Bekasi Regency General Election Commission are currently still local civil servants in Bekasi regency government, their workload is not included because Regional General Election Commission will be no longer local bureaucracy in the future.

From the calculation of workload according to Decree of Minister of Home Affairs No. 12 of 2008 on Guidelines for Workload Analysis in Department of Home Affairs and Local Government, the result is as follow:

\section{CONCLUSION}

From previous section, it can be concluded that:

1. Local Government Agencies in Bekasi Regency generally have high efficiency and effectiveness of work unit/position, considering that the organizational workload is greater than number of holder of the position (underload). There are 44 agencies that fall under the category of underload, with highest efficiency and effectiveness in Sukakarya District $(E U=2.59)$. Meanwhile, agencies with lowest efficiency and effectiveness of work unit/position is Environmental Control Agency $(E U=0.41)$.

2. There is shortage of personnel in all Local Government Agencies of Bekasi regency. Number of required personnel is 5,060 civil servants, while number of available personnel is only 3,502 civil servants (excluding civil servant of education and health workers, civil servants within Secretariat of General Election Commission, Local Hospital, Village Sekretary, and Expert Staff of Regent). Result of final calculation shows that there is shortage of personnel by 1,558 civil servants. This is understandable, considering the great complexity of administrative problems faced by Bekasi regency government since it is the buffer region for State Capital Region of Jakarta

\section{REFERENCES}

Flippo, Edwin.B (1976), Principles of personnel Management, Tokyo: MC.Graw-hill Kagakusha

Handoko, Hani.T (1994), Manajemen Personalia dan Sumber daya Manusia, Yogyakarta: BPFE

Hasibuan,Malayu.S.P (1997), Manajemen Sumber Daya Manusia dan Kunci Keberhasilan,Jakarta: Haji Masagung

Husna Suad \& Heiddjrachman (1997). Manajemen Personalia. Penerbit BPFE. Yogyakarta
Marwansyah dan Mukaram (2000), Manajemen Sumber Daya Manusia, Bandung: Poltek Negeri Bandung

Mitrani, Alain, et.all (1995) Manajemen Sumber Daya Manusia Berdasarkan Kompetensi,Jakarta: Interenasa

Mathis, Robert.L and Jackson, John (2001),Manajemen Sumber Daya Manusia, terjemahan Jimmy Sadell dan Bayu Prawira Hie, Jakarta: Selemba Empat

Moekijat (1989), Manajemen Kepegawaian, Bandung: Mandar Maju (1998). Analisis Jabatan. Penerbit Mandar Maju. Bandung

Munthe, Dame (1993) Analisis Jabatan dalam Praktek, Bandung: Mandar Maju

Musanef (1996), Manajemen Kepegawaian di Indonesia, Jakarta: PT.Toko Gunung Agung

Nawawi, Hadari (1992), Administrasi Personalia untuk Meningkatkan Produktifitas Kerja, Jakarta: Haji Masagung

Robbins, Stephen P. Teori Organisasi, Struktur, Desain dan Aplikasi. Edisi 3. Alih bahasa Yusuf Udaya, Penerbit Arcon. 1995.

Saydam GouzaJi (1996). Manajemen Sumber Daya Manusia. Penerbit Djambatan.

Sedarmayanti. 2000. Restrukturisasi dan Pemberdayaan Organisasi. Mandar Maju, Bandung

Siagian, Sondang.P (1996), Manajemen Sumber Daya Manusia, Jakarta: PT. Bumi Aksara

Simamora,Henry (2001), Manajemen Sumber Daya Manusia,Yogyakarta: STIE YKPN

Siswanto, Bedjo (1990), Organisasi Kepemimpinan dan Prilaku Administrasi, Jakarta: Haji Masagung

Tayibnapis, Burhannudin (1995), Administrasi Kepegawaian, Jakarta: PT Pradnya Paramita

The Liang Gie (1974), Administrasi Perkantoran Moderen, Yogyakarta: Nurcahaya

Thoha, Miftah, 1996. Perilaku Organisasi (Konsep Dasar dan Aplikasinya). PT Raja Grafindo Persada, Jakarta

Werther,William and Davis,Keith (1982), Personel Management and Human Resources, Tokyo: MC.Graw Hill Kogokusha 
Wexley Kenneth N \& Yulk Gary (1992). Perilaku Organisasi dan Psikologi Personalia. Penerbit Rineka Cipta.

Wursanto, IG (1997), Manajemen Kepegawaian 1, Yogyakarta: Kanisius

Yoder, Dale (1962), Personal: The Management of People at Work, New York: Mc Millan Publishing co.

Law and Regulations

Law of the Republic of Indonesia No. 32 of 2004 on Local Government

Law of the Republic of Indonesia No. 8 of 1974 on Personnel Principles in junction with Law No. 43 of 1999 on Amendment of Law No. 8 of 1974
Decree of Minister of Home Affairs of the Republic of Indonesia No. 12 of 2008 on Guidelines for Workload Analysis in Department of Home Affairs and Local Government

Decree of Head of State Civil Service Agency No. 19 of 2011 on Guidelines for Calculation of Required Civil Servant

Regional Regulation No. 7 of 2009 on Local Bureaucracies of Bekasi Regency

Regional Regulation No. 6 of 2011 on Amendment of Regional Regulation No. 7 of 2009 on Local Bureaucracies of Bekasi Regency 